\title{
Five generations of monazite in Langtang gneisses: implications for chronology of the Himalayan metamorphic core
}

\author{
M. J. KOHN, ${ }^{1}$ M. S. WIELAND, ${ }^{1}$ C. D. PARKINSON ${ }^{2}$ AND B. N. UPRETI ${ }^{3}$ \\ ${ }^{1}$ Department of Geological Sciences, University of South Carolina, Columbia, SC 29208, USA (mjk@geol.sc.edu) \\ ${ }^{2}$ Department of Geology and Geophysics, University of New Orleans, New Orleans, LA 70148, USA \\ ${ }^{3}$ Department of Geology, Tribhuvan University, Kathmandu, Nepal
}

\begin{abstract}
Monazite grains from Greater Himalayan Sequence gneisses, Langtang valley, Nepal, were chemically mapped and then dated in situ via $\mathrm{Th}-\mathrm{Pb}$ ion-microprobe analysis. Correlation of ages and chemistry reveals at least five different generations of monazite, ranging from c. 9 to $>300$ Ma. Petrological models of monazite chemistry provide a link between these generations and the thermal evolution of these rocks, yielding an age for the melting of Greater Himalayan rocks within the Main Central Thrust sheet (c. $16 \mathrm{Ma}$ ), and for the timing of thrust sheet emplacement that are younger than commonly viewed. Chemical characterization of monazite is vital prior to chronological microanalysis, and many ages previously reported for monazite from the Greater Himalayan Sequence are interpretationally ambiguous.
\end{abstract}

Key words: geochronology; Himalaya; melting; metamorphism; monazite.

\section{INTRODUCTION}

For two reasons, the Greater Himalayan Sequence is key for understanding Indo-Asian orogenesis. First, the Greater Himalayan Sequence is the metamorphic core of the Himalaya, having experienced the highest metamorphic temperatures and deepest burial of rocks now exposed on the surface. Second, ages of the Greater Himalayan monazite are the main bases for understanding the timing of initial thrust faulting in the Himalaya. Monazite is a focus for geochronological studies because it is common in metasedimentary rocks, and has low initial $\mathrm{Pb}$ contents, high $\mathrm{Pb}$ retentivity, and high U and Th contents (e.g. Parrish, 1990). Most Himalayan monazite ages have been collected in one of two ways: (i) via isotope-dilution, thermal ionization mass spectrometry (ID-TIMS) on individual grains or groups of grains that were separated according to physical appearance (Schärer, 1984; Copeland et al., 1988; Noble \& Searle, 1995; Hodges et al., 1996; Coleman, 1998; Simpson et al., 2000; Godin et al., 2001; Johnson et al., 2001; Daniel et al., 2003), or (ii) via in situ secondary ion-mass spectrometry (SIMS, or ion-microprobe) microanalysis of spots on different grains (Harrison et al., 1995, 1997; Edwards \& Harrison, 1997; Murphy \& Harrison, 1999; Foster et al., 2000; Catlos et al., 2001, 2002a,b, 2004; Kohn et al., 2001, 2004). Interpretation of these ages focused on resolving the structural relationships in the field (ID-TIMS and SIMS) or petrological distinction of matrix $v$. inclusion grains (SIMS). Three major age classes have been identified (Hodges et al., 1996; Catlos et al., 2001, 2002a,b; Johnson et al., 2001;
Viskupic \& Hodges, 2001): (i) a lower Palaeozoic age, possibly related to igneous activity and orogenesis (Gehrels et al., 2003); (ii) a 'main Himalayan' age of 25-20 Ma (although in one case extending to younger ages: Daniel et al., 2003), ascribed to initial thrusting on the Main Central Thrust; and (iii) an 'early Himalayan' age between $c .30$ and $c .50 \mathrm{Ma}$, the origins of which are unclear.

A summary of $\mathrm{U}-\mathrm{Pb}$ data for the two younger classes, updated from Harrison et al. (2002; Fig. 1) illustrates some of the difficulties in interpreting ages. Any age collected on a whole grain or group of grains could reflect varying degrees of reverse discordance, Palaeozoic inheritance, and/or mixing between different Cainozoic-age, intracrystalline domains. Because of the ambiguity in interpreting the chronological data, improving age resolution requires distinguishing these effects independent of chronological analysis.

In this study, it is argued that X-ray mapping and analysis of monazite chemistry are critical for correct interpretation of ages, and that this approach provides a better understanding of monazite ages and their tectonic significance. Analogous approaches have been attempted in a few other studies in the Himalaya, but with less detail. Foster et al. (2000) measured monazite compositions after in situ U-Th- $\mathrm{Pb}$ chronological analysis, and argued that monazite chemistry and age are linked; however, their identification of monaziteforming reactions and $P-T$ conditions was relatively unspecific. Viskupic \& Hodges (2001) collected backscattered electron images as guides for isotope analysis, but were unable to separate domains cleanly for IDTIMS analysis. Consequently, their data had multiple 


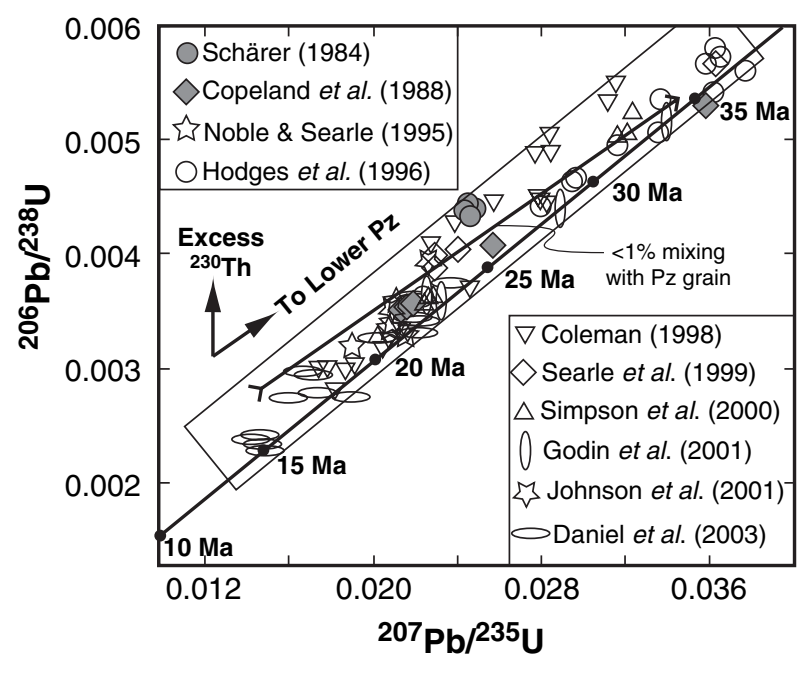

Fig. 1. Summary of $\mathrm{U}-\mathrm{Pb}$ ages for Himalayan monazite, illustrating temporal spread and inherent ambiguity in interpretation. Ages could reflect a combination of domains that are concordant, reversely discordant (short vertical arrow), inherited (short inclined arrow), and pre- or post-anatectic. Long arrow shows that $<1 \%$ contamination of a $16-15$ Ma typical reversely discordant monazite by high-U, Palaeozoic monazite found in this study would yield a composition that is isotopically indistinguishable from nearly concordant 35-34 Ma monazite grains. Modified from Harrison et al. (2002).

interpretations. Catlos et al. (2002b) measured chemical compositions near locations of previous SIMS analyses, and found large variations in monazite chemistry, but no clear correlation between chemistry and age. Because they did not characterize zoning to verify: (a) that the chemical compositions they measured were representative of the domains that were dated or (b) that SIMS analyses did not overlap chemically and chronologically distinct domains, their results also have ambiguities about the reliability of correlating chemistry and chronology. As described in this study, chemical characterization of monazite grains prior to chronological microanalysis of chemically distinguishable domains yields not three, but five distinct monazite generations, and permits at least four of them to be associated chemically with their metamorphic origins. These ages, in turn, yield new insights into the kinematics of Himalayan orogenesis - specifically an age of melting of the Main Central Thrust sheet that is younger than is commonly viewed, and clear documentation of coeval thrusting plus extension in the High Himalaya at c. $16 \mathrm{Ma}$.

\section{GEOLOGICAL BACKGROUND AND SAMPLES}

Samples were collected from the Greater Himalayan Sequence in Langtang Valley, Nepal (Fig. 2). Metamorphic zones in Greater Himalayan rocks include kyanite-muscovite, sillimanite-muscovite and sillimanite-K-feldspar, and metamorphic grade increases structurally upward. Muscovite dehydration-melting textures are ubiquitous in kyanite- and sillimanitebearing rocks (e.g. muscovite, plagioclase and quartz overgrowths on sillimanite, muscovite-rich leucosomes, etc.) and are especially important for estimating $P-T$ conditions. Considering the placement of the kyanite-sillimanite and muscovite dehydration-melting reactions (e.g. Spear et al., 1999), muscovite dehydration-melting requires a minimum temperature of $700{ }^{\circ} \mathrm{C}$ at a pressure of $8 \mathrm{kbar}$. Reconnaissance thermobarometry (Kohn et al., 2004; Fig. 2) yields $P-T$ conditions consistent with this petrological fact $T \geq 750{ }^{\circ} \mathrm{C}$ for sillimanite-grade rocks, similar to results first obtained by Inger \& Harris (1992). These observations reinforce long-standing arguments that partial melting reactions are integral to the metamorphic evolution of these rocks (Inger \& Harris, 1992; Harris et al., 1993; Harris \& Massey, 1994). Partial melting reactions are also critical for understanding chemical zoning in monazite.

\section{ANALYTICAL METHODS}

Electron-microprobe data (Table S1) were collected by using the fully automated Cameca SX-50 housed in the Electron Microscopy Center, University of South Carolina. These data were used to guide chronological analysis of monazite and to characterize compositional differences that could be linked to petrological and structural discontinuities (Table S1). For X-ray maps, an accelerating voltage of $15 \mathrm{kV}$ was used, a cup current of $200 \mathrm{nA}$, and time per pixel of $30 \mathrm{~ms}$, with a pixel resolution dependent on crystal size - typically 1$2 \mu \mathrm{m}$. For quantitative analyses of monazite, operating conditions were $20 \mathrm{kV}$ accelerating voltage, $20 \mathrm{nA}$ cup current, and a spot size of $5 \mu \mathrm{m}$. Synthetic phosphates and a natural apatite were used as standards.

Ion-microprobe $\mathrm{Th}-\mathrm{Pb}$ analyses of monazite grains (Table S1) were collected in situ with the Cameca IMS 1270 housed at the Department of Earth and Space Sciences, University of California, Los Angeles. Monazite grains were first identified in thin section and mapped for Th, U, Y and Si distributions by electron microprobe. Individual grains were then drilled out using either a $1 / 4^{\prime \prime}$ or $1 / 8^{\prime \prime}$ diamond drill corer. Most crystals were relatively large, chemically complex matrix grains, but some inclusions were also analysed (Table S1). Grains were mounted together with the UCLA 554 monazite standard in $1^{\prime \prime}$ epoxy rounds. Operating conditions are essentially as described previously (Harrison et al., 1995), and for this study involved a primary beam current of 6-12 nA, a spot size of $c$. $10-30 \mu \mathrm{m}$, energy offsets for ${ }^{232} \mathrm{Th}^{+}$and $\mathrm{ThO}_{2}^{+}$of +10 to $15 \mathrm{eV}$ and -8 to $-13 \mathrm{eV}$, respectively, and a mass resolving power of $c$. 5000, which was sufficient to discriminate peak interferences. Total analysis time per spot was $c$. 15 min. Common $\mathrm{Pb}$ corrections assumed ${ }^{208} \mathrm{~Pb} /{ }^{204} \mathrm{~Pb}=38.6$ (Stacey \& Kramers, 1975), but alternative assumptions do not yield significantly different ages (Table S1). Reported age uncertainties 


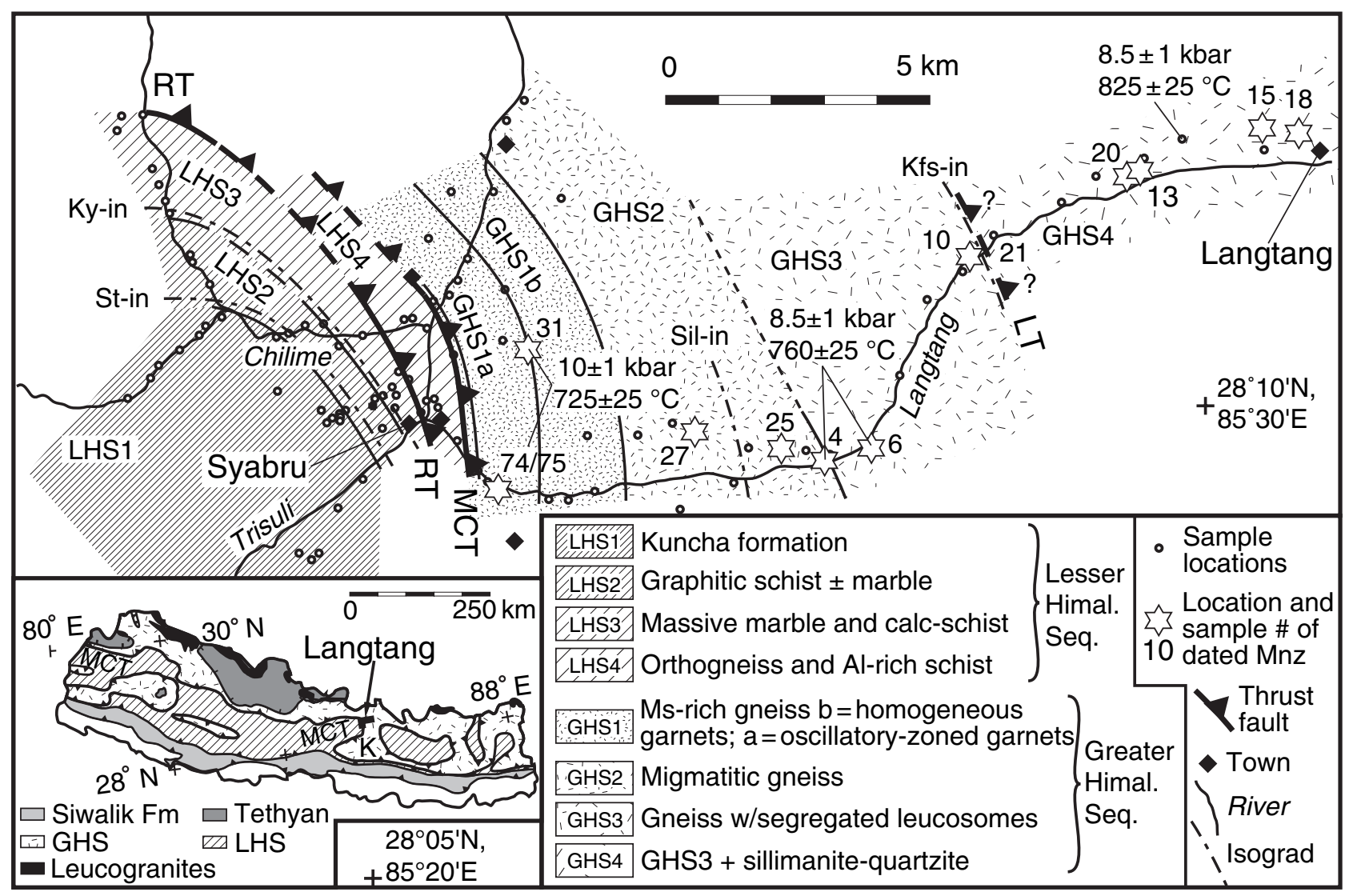

Fig. 2. Geological map of Langtang region, showing sample locations, lithological units, isograds, inferred thrusts, towns (specifically Langtang and Syabru) and major rivers (Langtang, Trisuli, and Chilime). $P-T$ conditions are from Kohn et al. (2004) and account for the effects of retrograde net-transfer reactions on mineral compositions (Kohn \& Spear, 2000). Units GHS1 to GHS4 correspond with Formation 1 of the Greater Himalayan Sequence (Le Fort, 1975). Units LHS1 to LHS4 correspond to rocks of the Lesser Himalayan Sequence. LT, RT and MCT are the Langtang, Ramgarh, and Main Central Thrusts respectively. As shown here, the Main Central Thrust is drawn at the contact between Greater and Lesser Himalayan Sequences; penetrative deformation is present both above and below it. Inset shows location of Langtang study area within Nepal.

reflect counting statistics and the reproducibility of the ${ }^{264} \mathrm{ThO}_{2}^{+} / 232 \mathrm{Th}^{+} v .{ }^{208} \mathrm{~Pb}^{*+} / 232 \mathrm{Th}^{+}$calibration curve, as determined from multiple spots on the standard.

\section{CHEMICAL SYSTEMATICS OF MONAZITE}

Chemical changes to monazite during metamorphism are key for interpreting different generations of monazite and their ages (Fig. 3). Numerous studies have shown that accessory minerals, such as monazite, participate in reactions involving major silicates, and most researchers strive to identify a chemical tracer in monazite that can be linked to silicate reactions and in turn to metamorphic evolution (e.g. Pyle \& Spear, 1999, 2003; Ferry, 2000; Foster et al., 2000, 2004; Pyle et al., 2001, 2005; Spear \& Pyle, 2002; Wing et al., 2003; Gibson et al., 2004; Kohn \& Malloy, 2004; Dahl et al., 2005). For monazite, $\mathrm{Y}$ and $\mathrm{Th}$ are good tracers because they are strongly and systematically zoned, and because their variations can be linked to silicate reactions and trace-element mass balance.

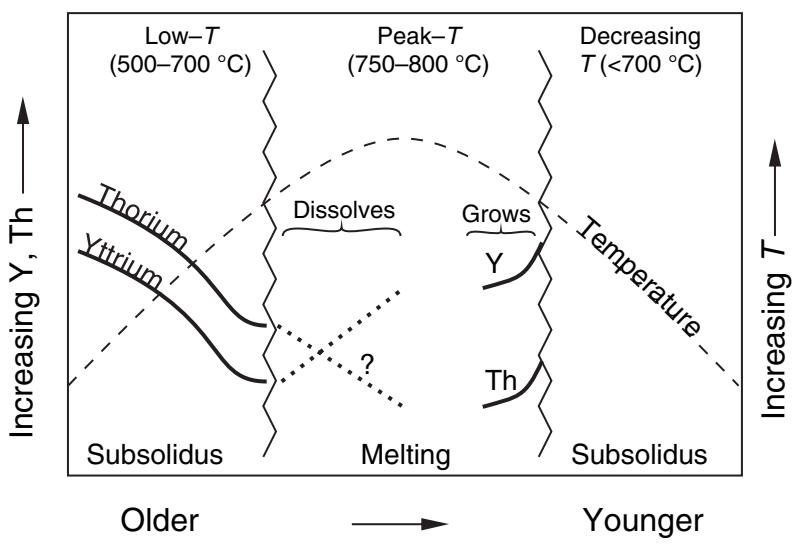

Fig. 3. Schematic petrological guide for interpreting metamorphic monazite chemistry. Monazite first grows with elevated Y and Th. As temperature increases, Y and Th decrease. During melting, monazite dissolves. During melt crystallization, monazite reforms, with increasingly elevated $\mathrm{Y}$ and depleted but increasing Th contents. The question mark for Th indicates that the understanding of Th systematics during melting is particularly poor. 
Thorium occurs only in trace amounts in all common pelitic minerals except for monazite (typically c. $4 \mathrm{wt} \%$; Spear \& Pyle, 2002) and allanite (typically c. $1 \mathrm{wt} \%$; Gieré \& Sorensen, 2004). Although allanite can be an important host for Th in some rocks of the Lesser Himalayan Sequence (e.g. Catlos et al., 2000, 2001), we found no allanite in rocks of the Greater Himalayan Sequence. Regardless, the preference of monazite for Th relative to all other common major and accessory minerals, including allanite, causes it to fractionate $\mathrm{Th}$ in a Rayleigh-like manner as it grows (Kohn \& Malloy, 2004). Earlier, lower-grade monazite will have a high Th content, with decreasing Th towards rims or in later-grown grains (Fig. 3).

Yttrium systematics are more complicated chemically because $\mathrm{Y}$ can be hosted by more minerals principally garnet, monazite, allanite and xenotime (Spear \& Pyle, 2002). There is no evidence for prograde xenotime or allanite in our rocks, based on monazite and garnet compositions (generally low Y content) and imaging with the electron microprobe. Therefore, Y contents of monazite depend almost exclusively on reactions involving garnet (Pyle \& Spear, 1999, 2003; Pyle et al., 2001). Garnet generally grows during prograde metamorphism, sequestering $\mathrm{Y}$ in its interior, and driving later generations of monazite (and garnet) to lower $\mathrm{Y}$ contents. Thus, at least in subsolidus rocks, the lowest-Y monazite likely represents the conditions at which garnet was most abundant - i.e. most generally at the highest grade. HigherY monazite grains or domains likely represent earlier generations formed at lower temperatures, much as expected for Th (Fig. 3).

Partial melting radically changes compositional trends in monazite. Although garnet continues to grow (Spear et al., 1999), implying a decrease in Y concentrations, high phosphorus solubility in the melt may cause monazite to dissolve in many rocks, liberating $\mathrm{Y}$ and Th (Spear \& Pyle, 2002). In one study, a new generation of monazite was inferred to have formed during biotite dehydration-melting (Watt \& Harley, 1993), but it was extremely Th-rich $\left(>20 \mathrm{wt} \% \mathrm{ThO}_{2}\right)$, unlike any monazite compositions we have found. More importantly, the main melting reaction in the rocks was muscovite dehydration melting, producing peraluminous melts. Because Al-complexing increases P solubility (Wolf \& London, 1994), monazite dissolution is expected to occur during this reaction, eradicating direct chemical or chronological records in monazite of melting. However, upon cooling, monazite regrows while garnet dissolves, so a post-melting generation of monazite should be present, and indeed we infer major production of monazite because of melt crystallization during initial cooling.

Considering that monazite partitions $\mathrm{Y}$ much more strongly than any other mineral present or the melt, and that garnet liberates $\mathrm{Y}$ via dissolution during melt crystallization, newly grown monazite will most likely have high Y. Trends of thorium are not readily pre- dicted during melting and melt crystallization, because there is a very poor understanding of where Th resides outside monazite. However, in monazite grains that we have analysed, high-Y rims have low Th concentrations, perhaps implying that some reservoir exists for Th during melting besides the major silicates. Further cooling and melt crystallization could lead to either increasing or decreasing $\mathrm{Y}$ and $\mathrm{Th}$ on monazite rims, depending on mineral-melt $Y$ and Th partition coefficients, and the relative crystallization rates of $Y$ - and Th-poor minerals such as muscovite $v$. Y-rich monazite. Most monazite grains characterized have increasing $\mathrm{Y}$ and $\mathrm{Th}$ towards their rims (Fig. 3). In sum, simple $\mathrm{Y}$ and $\mathrm{Th}$ mass balance provides a guide for interpreting ages - lowest-Y and -Th monazite represents the immediate pre-melting stage, whereas high-Y overgrowths represent melt crystallization. All other chemistries and ages can then be interpreted within this chemical framework.

\section{RESULTS AND INTERPRETATIONS}

Because monazite chemistry is so critical to age interpretation, it was first characterized via the electron microprobe, prior to $\mathrm{Th}-\mathrm{Pb}$ isotopic analysis via SIMS (see also Kohn et al., 2004). Greater Himalayan monazite grains show significant Y-zoning (Fig. 4). Most commonly, we observe single grains with low-Y cores, and high-Y overgrowths (Fig. $4 \mathrm{a}-\mathrm{c}$ ). Some grains are nearly homogeneous compositionally, but they are by far the least common, and in fact do contain evidence for other generations (Fig. 4d,e). That is, the vast majority of grains contain multiple, chronologically and chemically distinct domains. Some grains have 'mottled' zoning that is not readily assignable to a specific generation (Fig. 4f) - these have relatively elevated $\mathrm{Y}$ and old ages, consistent with a sub-solidus metamorphic origin on the prograde path. Two grains are unusual. One is cut by a late-stage fracture with clay formation in the surrounding feldspar (Fig. 4g). Tiny xenotime grains associated with low-Y monazite along the fracture indicate that the monazite exsolved or recrystallized along the monazite-xenotime solvus. However, the $\mathrm{Y}+\mathrm{HREE}$ content of the monazite is so low $\left(X_{\mathrm{YPO}_{4}}<0.015\right.$; Table S1) that this reaction must have occurred at $<400{ }^{\circ} \mathrm{C}$ (Spear \& Pyle, 2002). This inference is consistent with older ${ }^{40} \mathrm{Ar} /{ }^{39} \mathrm{Ar}$ ages from muscovite in rocks nearby (Macfarlane, 1993), implying that the monazite formed below the closure temperature of muscovite $\left(c .400{ }^{\circ} \mathrm{C}\right.$; McDougall \& Harrison, 1999). One monazite inclusion in garnet is also unusual in having Palaeozoic ages up to c. $450 \mathrm{Ma}$, and an extremely elevated $\mathrm{U}$ content (c. $3 \mathrm{wt} \%$ v. $0.5 \mathrm{wt} \%$ for all other analyses of grains both in the same sample and in other samples; Fig. 4h). This grain is clearly out of chemical equilibrium. It may be detrital or alternatively hydrothermal, i.e. it may have formed at too low a temperature either to equilibrate, or to assume a composition 

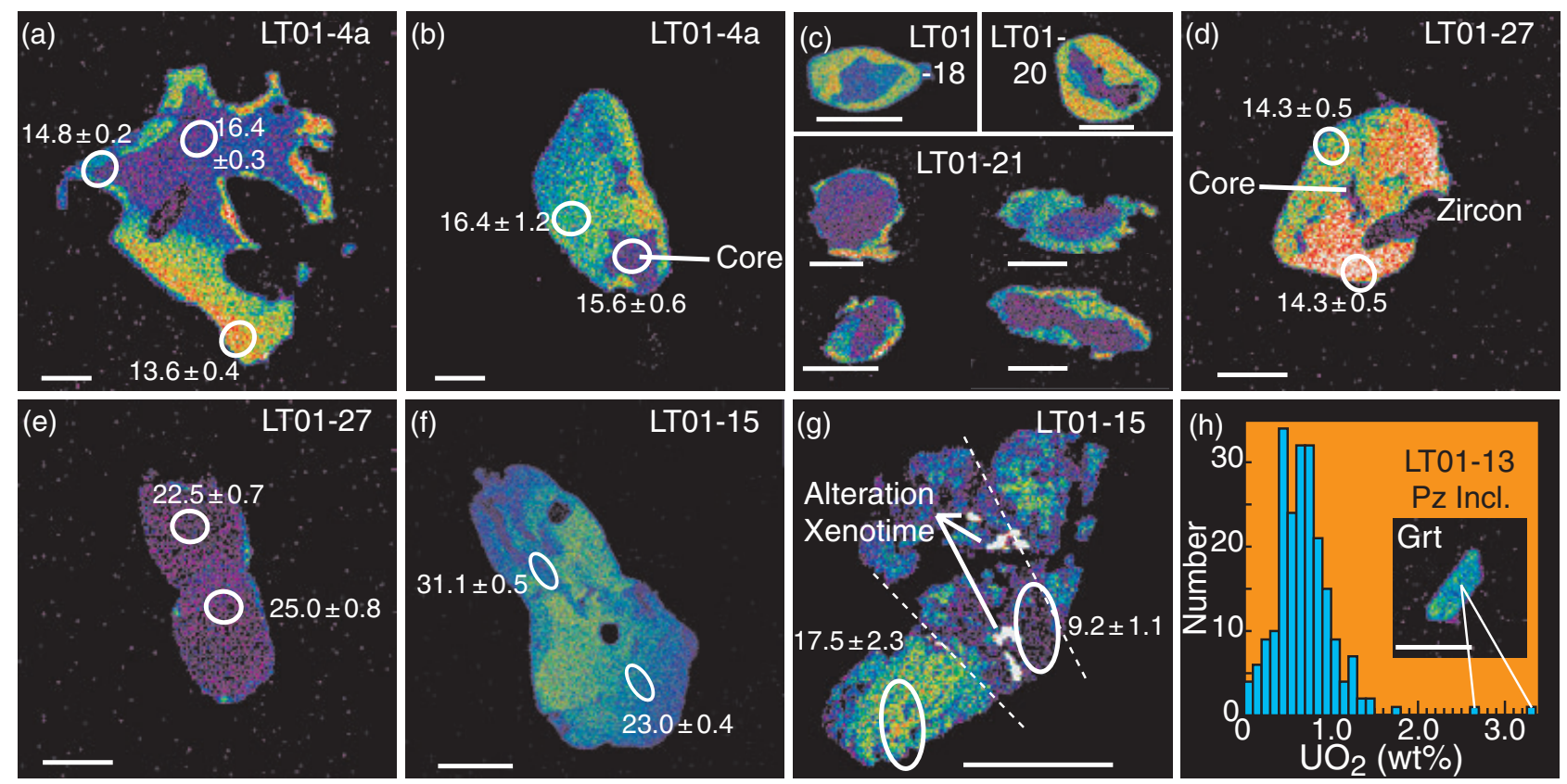

Fig. 4. X-ray maps of $\mathrm{Y}$ in monazite, illustrating chemically and chronologically distinct domains. White ovals with ages are SIMS analysis spots. Uncertainties are $\pm 2 \sigma$; scale bars are all $50 \mu \mathrm{m}$; Th zoning generally delineates the same domains but is less dramatic. $(\mathrm{a}, \mathrm{b}, \mathrm{c})$ Monazite grains show obvious low-Y cores, overgrown by younger, high-Y rims. (d, e) A nearly uniform high-Y grain retains a tiny core, whereas an older low-Y composite grain has thin high-Y rims. (f) An example of non-diagnostic zoning, this grain has a general decrease in $\mathrm{Y}$ towards its rim, as well as older ages than either low-Y grains/cores, or uniformly high-Y grains/rims from monazite in the same rock or in nearby rocks. (g) Co-precipitation of retrograde, low-Y monazite plus xenotime has occurred along a late-stage crack (bounded by dotted lines). (h) Histogram of $\mathrm{UO}_{2}$ contents of monazite, illustrating anomalously high $\mathrm{UO}_{2}$ for a Palaeozoic inclusion in garnet.

commensurate with higher-temperature monazite formation. Lower Palaeozoic monazite has been identified in previous studies (Noble \& Searle, 1995; Hodges et al., 1996; Catlos et al., 2001, 2002a,b; Viskupic \& Hodges, 2001), and constitutes one of the main age classes for Greater Himalayan rocks.

Age probability diagrams for monazite (Fig. 5) show distinct peaks that also correspond to distinct chemistries, and hence to petrological origins. Of particular importance is the timing of the last growth of prograde sub-solidus monazite (youngest low-Y and -Th peak) $v$. the timing of final melt crystallization during cooling (high-Y overgrowth), which together bracket the timing of melting. In the structurally highest rocks near Langtang village (Fig. 5a), the last prograde monazite that formed in a solid-state assemblage (low-Y monazite) has an age of $c$. 22-23 Ma, whereas crystallization of in situ melts (high-Y monazite overgrowth) occurred at c. $18 \mathrm{Ma}$, indicating melting at c. $20 \pm$ $2 \mathrm{Ma}$. Structurally lower rocks have exactly the same chemically defined generations of monazite, but displaced to younger ages - as young as $16 \mathrm{Ma}$ for low-Y monazite, and 15-13 Ma for high-Y rims (Figs 4a,b,d \& $5 b)$. This indicates that both packages of rocks underwent similar reactions (specifically muscovite dehydration-melting, followed by melt crystallization), but at different times. Because of these disparities, Kohn et al. (2004) tentatively identified a thrust at

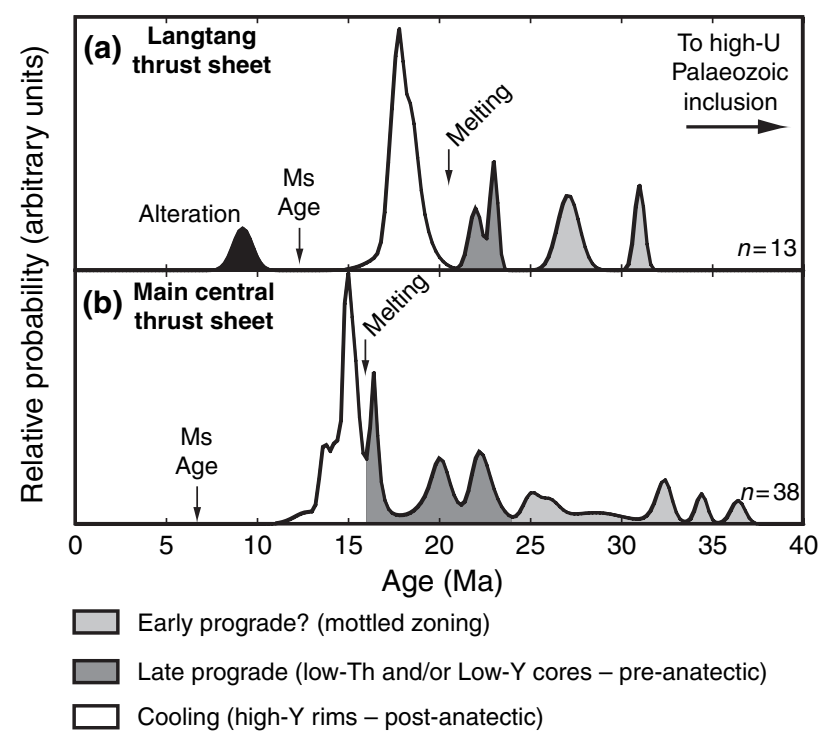

Fig. 5. Probability distributions of monazite ages, distinguished according to monazite chemistry. Arrows show published

${ }^{40} \mathrm{Ar} /{ }^{39} \mathrm{Ar}$ ages from same structural levels (Macfarlane, 1993). (a) Highest structural level (Langtang Thrust sheet). (b) Main Central Thrust sheet. Data from Kohn et al. (2004).

the K-feldspar isograd (Fig. 2; the Langtang Thrust). We do note that an alternative interpretation of the high-Y overgrowths as forming during melting 
(e.g. Watt \& Harley, 1993) would simply decrease the age of melting by $c$. 1-4 Myr in all samples; an age disparity of melting would still exist between structurally high and low rocks, and the age of melting in the Main Central Thrust sheet would be 15 Ma.

Two other generations of metamorphic monazite are clearly distinguishable. Alteration monazite yields a c. 9 Ma age, whereas the compositionally anomalous inclusion yields Palaeozoic ages (well off the scale of Fig. 5a). Neither generation was found in structurally lower rocks. The other monazite grains analysed do have compositional zoning, but without the clear distinction of low-Y core $v$. high-Y rim, unusual U content, or textural and chemical association with alteration. The generally high $\mathrm{Y}$ and broadly decreasing Y from core to rim (e.g. Fig. 4f), suggest an early prograde metamorphic origin. This accords with ages exceeding $25 \mathrm{Ma}$.

Because temperatures were so high, modification of ages because of $\mathrm{Pb}$ diffusion is worth considering. However, recent studies (Cherniak et al., 2004) indicate that effects of volume diffusion should be unmeasurable over distances $>1 \mu \mathrm{m}$. The co-separation of monazite ages and chemistry observed in this study also supports an absence of diffusional resetting or bias. If all subsolidus monazite were reset, e.g. during melting, then they would yield similar ages regardless of chemistry clearly they do not (Fig. 5). Furthermore, the most important ages for tectonic interpretations are those bracketing the timing of melting, particularly the high-Y rims formed during melt crystallization. Postcrystallization cooling rates were simply too fast $\left(50{ }^{\circ} \mathrm{C} \mathrm{Myr}^{-1}\right.$; Kohn et al., 2004) to cause significant age bias.

\section{DISCUSSION}

Crystallization of in situ late-stage leucosomes for the Greater Himalayan Sequence is commonly assigned an age of c. $22 \mathrm{Ma}$, based on ID-TIMS ages from leucosome monazite and zircon (Hodges et al., 1996; Johnson et al., 2001), although some studies have also suggested protracted melting over $c$. $10 \mathrm{Myr}$ from nearly $30 \mathrm{Ma}$ to $c .20 \mathrm{Ma}$ (e.g. see Viskupic \& Hodges, 2001). The c. $22 \mathrm{Ma}$ ages were obtained from structural levels most similar to our Langtang Thrust sheet - either very high in the Greater Himalayan sequence or from a thrust sheet that may pre-date the Main Central Thrust. The general consistency of our dates compared with those of Hodges et al. (1996) and Johnson et al. (2001) certainly supports their observations and conclusions, at least at this structural level. However, we found no conclusive evidence for multiple melting events. Older (c. $30 \mathrm{Ma})$ ages $v$. younger (c. $20 \mathrm{Ma}$ ) ages are certainly present in a single rock, but these could simply record monazite formed via early prograde solid-state metamorphism $v$. late-stage melt crystallization. Furthermore, focusing on the youngest stage of melt crystallization, our data show there is no single 'event' applicable to all Greater Himalayan rocks. Although many monazite grains do record melt crystallization, both chemically and chronologically, this occurred at $16 \pm 1 \mathrm{Ma}$ in structurally low rocks from the Main Central Thrust sheet, not at c. $22 \mathrm{Ma}$.

This revised age of peak metamorphism and initial cooling for the Main Central Thrust have important implications for Himalayan convergence rates. Assuming that cooling resulted from thrusting, a younger age significantly compresses the time during which the Main Central Thrust could have been active - it must be $\leq 16 \mathrm{Ma}$, yet $\geq 8-10 \mathrm{Ma}$, when deformation had clearly propagated into Lesser Himalayan rocks (Harrison et al., 1997; Catlos et al., 2001, 2002a,b; Daniel et al., 2003; Kohn et al., 2004). For a given displacement amount, e.g. as derived either structurally (DeCelles et al., 2001) or from thermal models (Kohn et al., 2004), this then implies faster thrusting rates than would otherwise be calculated. In fact, using petrological arguments and theoretical thermal models, Kohn et al. (2004) inferred thrusting rates of $c$. $2 \mathrm{~cm} \mathrm{year}^{-1}$ for the Main Central and Langtang thrusts, indistinguishable from measured convergence rates across the Himalaya today (Bilham et al., 1997; Larson et al., 1999).

A revised age for movement of the Main Central Thrust is also important for evaluating whether thrusting was coeval with extension on the South Tibetan Detachment system, i.e. whether the Greater Himalayan Sequence was extruded as a wedge between these bounding fault systems (Hodges et al., 1992). Initial extension in eastern Nepal was originally believed to be synchronous with movement of the 'Main Central Thrust' at 22-20 Ma (e.g. Hodges et al., 1992), implying that the Greater Himalayan Sequence was indeed extruded between thrust and normal faults. Subsequently, the age for the South Tibetan Detachment system in eastern Nepal was revised downward to $\leq 16-17$ Ma (e.g. Harrison et al., 1998; Hodges et al., 1998; Murphy \& Harrison, 1999; although evidence for older extension was also found elsewhere, e.g. Inger, 1998; Harrison et al., 1999). With the revisions, movement along the South Tibetan Detachment system was potentially distinct in age from the old (22-20 Ma) 'Main Central Thrust,' possibly implying alternating periods of thickening and thinning (e.g. Hodges et al., 1996). However, as argued here, the older 'Main Central Thrust' ages may reflect movement at a different, higher structural level. Because initial movement on the Main Central Thrust occurred at $16 \pm 1 \mathrm{Ma}$ in Nepal (this study), coeval thrust and normal fault movement is again chronologically permissible. This wedge-extrusion model explains well the exposure of high-grade metamorphic rocks of both the Greater and Lesser Himalayan Sequence.

More generally, as noted by Viskupic \& Hodges (2001) and Harrison et al. (2002), there are serious interpretational ambiguities for most published ages 
for Greater Himalayan monazite, particularly for TIMS analyses of single or multiple grains. As shown by our data, there can be five different generations of monazite of varying age and composition, and even ignoring Palaeozoic grains, ages can span over $20 \mathrm{Myr}$. A specific age for a grain fragment, single grain, or group of grains analysed by ID-TIMS could be a 'real' age (i.e. corresponding to a specific generation of monazite), or a meaningless mixture of inherited, prograde sub-solidus and/or retrograde domains (Harrison et al., 2002). That is, mixed analyses of multiple young domains would shift ages along concordia and may be one reason why ID-TIMS analysis has defined only two different age classes for the younger monazite, compared with four in this study. Insofar as monazite is able to withstand partial melting and may be transported in melts (Copeland et al., 1988; Harrison et al., 1995, 1999; see also Watt \& Harley, 1993), this issue is relevant not only to Himalayan metamorphic monazite, but also to igneous monazite that is used in the investigation of crosscutting structural relationships.

Inherited Palaeozoic domains in late Cainozoic monazite grains are especially problematic because as little as $1 \%$ contamination by the high-U monazite described in this study would yield as much as a $20 \mathrm{Myr}$ bias to a bulk $\mathrm{U}-\mathrm{Pb}$ age. The slope of such a mixing line is nearly parallel to concordia (Fig. 1), and many monazite grains have excess ${ }^{230} \mathrm{Th}$ upon crystallization (Schärer, 1984; Fig. 1). Consequently, identifying this contamination is virtually impossible by isotope measurements alone (Fig. 1) - minute contamination could easily lead to more nearly concordant (i.e. 'better') analyses that are in fact substantially inaccurate. Analytical mixing problems are not unique to ID-TIMS, because SIMS analytical spots can also overlap domains with different chemistries and ages. Instead, useful assignment of ages for monazite will first require characterizing chemistry, followed by selective chronological analysis of specific chemical domains, either via in situ techniques (e.g. SIMS or laser-ablation ICP-MS), or via microsampling combined with ID-TIMS.

\section{ACKNOWLEDGEMENTS}

We thank M. Grove and A. Schmitt for their help with the ion probe, and T. Ojha for field support. This material is based upon work supported by the National Science Foundation under Grant Nos. EAR 0073803 and 0309470 to MJK. J Pyle and P Dahl are thanked for their reviews, which helped clarify several points in this study.

\section{SUPPLEMENTARY MATERIAL}

Table S1. Monazite ages and compositions from Greater Himalayan Sequence rocks, Langtang valley, Nepal.

\section{REFERENCES}

Bilham, R., Larson, K. M., Freymueller, J. T. for the Project Idylhim, 1997. GPS measurements of present-day convergence across the Nepal Himalaya. Nature, 386, 61-64.

Catlos, E. J., Sorensen, S. S. \& Harrison, T. M., 2000. Th-Pb ion-microprobe dating of allanite. American Mineralogist, 85, 633-648.

Catlos, E., Harrison, T. M., Kohn, M. J. et al., 2001. Geochronologic and thermobarometric constraints on the evolution of the Main Central Thrust, central Nepal Himalaya. Journal of Geophysical Research, 106, 16177-16203.

Catlos, E. J., Harrison, T. M., Manning, C. E. et al., 2002a. Records of the evolution of the Himalayan orogen from in situ $\mathrm{Th}-\mathrm{Pb}$ ion microprobe dating of monazite: Eastern Nepal and Garhwal. Journal of Asian Earth Sciences, 20, 459-479.

Catlos, E. J., Gilley, L. D. \& Harrison, T. M., 2002b. Interpretation of monazite ages obtained via in situ analysis. Chemical Geology, 188, 193-215.

Catlos, E. J., Dubey, C. S., Harrison, T. M. \& Edwards, M. A., 2004. Late Miocene movement within the Himalayan Main Central Thrust shear zone, Sikkim, north-east India. Journal of Metamorphic Geology, 22, 207-226.

Cherniak, D. J., Watson, E. B., Grove, M. \& Harrison, T. M., 2004. $\mathrm{Pb}$ diffusion in monazite: a combined RBS/SIMS study. Geochimica et Cosmochimica Acta, 68, 829-840.

Coleman, M. E., 1998. U-Pb constraints on Oligocene-Miocene deformation and anatexis within the central Himalaya, Marsyandi Valley, Nepal. American Journal of Science, 298, 553-571.

Copeland, P., Parrish, R. R. \& Harrison, T. M., 1988. Identification of inherited radiogenic $\mathrm{Pb}$ in monazite and its implications for U-Pb systematics. Nature, 333, 760-763.

Dahl, P. S., Hamilton, M. A., Jercinovic, M. J., Terry, M. P., Williams, M. L. \& Frei, R., 2005. Comparative isotopic and chemical geochronometry of monazite, with implications for $\mathrm{U}-\mathrm{Th}-\mathrm{Pb}$ dating by electron microprobe: an example from metamorphic rocks of the eastern Wyoming Craton (U.S.A.). American Mineralogist, 90, 619-638.

Daniel, C. G., Hollister, L. S., Parrish, R. R. \& Grujic, D., 2003. Exhumation of the Main Central Thrust from lower crustal depths, eastern Bhutan Himalaya. Journal of Metamorphic Geology, 21, 317-334.

DeCelles, P. G., Robinson, D. M., Quade, J. et al., 2001. Stratigraphy, structure, and tectonic evolution of the Himalayan fold-thrust belt in western Nepal. Tectonics, 20, 487-509.

Edwards, M. A. \& Harrison, T. M., 1997. When did the roof collapse? Late Miocene north-south extension in the high Himalaya revealed by $\mathrm{Th}-\mathrm{Pb}$ monazite dating of the Khula Kangri Granite. Geology, 25, 543-546.

Ferry, J. M., 2000. Patterns of mineral occurrence in metamorphic rocks. American Mineralogist, 85, 1573-1588.

Foster, G., Kinny, P., Vance, D., Prince, C. I. \& Harris, N., 2000. The significance of monazite U-Th-Pb age data in metamorphic assemblages; a combined study of monazite and garnet chronometry. Earth and Planetary Science Letters, 181, 327 340.

Foster, G., Parrish, R. R., Horstwood, M. S. A., Chenery, S., Pyle, J. M. \& Gibson, H. D., 2004. The generation of prograde P-T-t points and paths; a textural, compositional, and chronological study of metamorphic monazite. Earth and Planetary Science Letters, 228, 125-142.

Gehrels, G. E., DeCelles, P. G., Martin, A., Ojha, T. P., Pinhassi, G. \& Upreti, B. N., 2003. Initiation of the Himalayan orogen as an early Paleozoic thin-skinned thrust belt. GSA Today, 13, 4-9.

Gibson, H. D., Carr, S. D., Brown, R. L. \& Hamilton, M. A., 2004. Correlations between chemical and age domains in monazite, and metamorphic reactions involving major pelitic phases: an integration of ID-TIMS and SHRIMP geochronology with Y-Th-U X-ray mapping. Chemical Geology, 211, $237-260$ 
Gieré, R. \& Sorensen, S. S., 2004. Allanite and other REE-rich epidote-group minerals. Review in Mineralogy and Geochemistry, 56, 431-493.

Godin, L., Parrish, R. R., Brown, R. L. \& Hodges, K. V., 2001. Crustal thickening leading to exhumation of the Himalayan metamorphic core of central Nepal: insight from U-Pb geochronology and ${ }^{40} \mathrm{Ar} /{ }^{39} \mathrm{Ar}$ thermochronology. Tectonics, 20 , 729-747.

Harris, N. \& Massey, J., 1994. Decompression and anatexis of Himalayan metapelites. Tectonics, 13, 1537-1546.

Harris, N., Inger, S. \& Massey, J., 1993. The role of fluids in the formation of High Himalayan leucogranites. In: Himalayan Tectonics, vol. 74 (eds Treloar, P.J. \& Searle, M.P.), pp. 391400. Geological Society of London, London.

Harrison, T. M., McKeegan, K. D. \& Le Fort, P., 1995. Detection of inherited monazite in the Manaslu leucogranite by ${ }^{208} \mathrm{~Pb} /{ }^{232}$ Th ion microprobe dating: crystallization age and tectonic significance. Earth and Planetary Science Letters, 133, 271-282.

Harrison, T. M., Ryerson, F. J., Le Fort, P., Yin, A., Lovera, O. M. \& Catlos, E. J., 1997. A late Miocene-Pliocene origin for the central Himalayan inverted metamorphism. Earth and Planetary Science Letters, 146, E1-E7.

Harrison, T. M., Grove, M., Lovera, O. M. \& Catlos, E. J., 1998. A model for the origin of Himalayan anatexis and inverted metamorphism. Journal of Geophysical Research, 103, 2701727032.

Harrison, T. M., Grove, M., McKeegan, K. D., Coath, C. D., Lovera, O. M. \& Le Fort, P., 1999. Origin and episodic emplacement of the Manaslu intrusive complex, Central Himalaya. Journal of Petrology, 40, 3-19.

Harrison, T. M., Catlos, E. J. \& Montel, J.-M., 2002. U-Th-Pb dating of phosphate minerals. Reviews in Mineralogy, 48, 523558 .

Hodges, K. V., Parrish, R. R., Housh, T. B. et al., 1992. Simultaneous Miocene extension and shortening in the Himalayan Orogen. Science, 258, 1466-1470.

Hodges, K. V., Parrish, R. R. \& Searle, M. P., 1996. Tectonic evolution of the central Annapurna Range, Nepalese Himalayas. Tectonics, 15, 1264-1291.

Hodges, K. V., Bowring, S. A., Davidek, K. L., Hawkins, D. \& Krol, M., 1998. Evidence for rapid displacement on Himalayan normal faults and the importance of tectonic denudation in the evolution of mountain ranges. Geology, 26, 483-486.

Inger, S., 1998. Timing of an extensional detachment during convergent orogeny; new $\mathrm{Rb}-\mathrm{Sr}$ geochronological data from the Zanskar shear zone, northwestern Himalaya. Geology, 26, 223-226.

Inger, S. \& Harris, N. B. W., 1992. Tectonothermal evolution of the High Himalayan crystalline sequence, Langtang Valley, northern Nepal. Journal of Metamorphic Geology, 10, 439452.

Johnson, M. R. W., Oliver, G. J. H., Parrish, R. R. \& Johnson, S. P., 2001. Synthrusting metamorphism, cooling, and erosion of the Himalayan Kathmandu Complex, Nepal. Tectonics, 20, 394-415.

Kohn, M. J. \& Malloy, M. A., 2004. Formation of monazite via prograde metamorphic reactions among common silicates: implications for age determinations. Geochimica et Cosmochimica Acta, 68, 101-113.

Kohn, M. J. \& Spear, F. S., 2000. Retrograde net transfer reaction insurance for pressure-temperature estimates. Geology, 28, 1127-1130.

Kohn, M. J., Catlos, E. J., Ryerson, F. J. \& Harrison, T. M., 2001. Pressure-temperature-time path discontinuity in the Main Central thrust zone, central Nepal. Geology, 29, 571574.

Kohn, M. J., Wieland, M. S., Parkinson, C. D. \& Upreti, B. N., 2004. Miocene faulting at plate tectonic velocity in the central Himalaya, Nepal. Earth and Planetary Science Letters, 228, 299-310.
Larson, K. M., Bürgmann, R., Bilham, R. \& Freymueller, J. T., 1999. Kinematics of the India-Eurasia collision zone from GPS measurements. Journal of Geophysical Research, 104, 1077-1093.

Le Fort, P., 1975. Himalayas; the collided range; present knowledge of the continental arc. American Journal of Science, 275-A, 1-44.

Macfarlane, A. M., 1993. Chronology of tectonic events in the crystalline core of the Himalaya, Langtang National Park, central Nepal. Tectonics, 12, 1004-1025.

McDougall, I. \& Harrison, T. M., 1999. Geochronology and thermochronology by the ${ }^{40} \mathrm{Ar} /{ }^{39} \mathrm{Ar}$ method. Oxford Monographs on Geology and Geophysics, 2nd edn, vol. 9, pp. 269.

Murphy, M. A. \& Harrison, T. M., 1999. Relationship between leucogranites and the Qomolangma Detachment in the Rongbuk Valley, South Tibet. Geology, 27, 831-834.

Noble, S. R. \& Searle, M. P., 1995. Age of crustal melting and leucogranite formation from U-Pb zircon and monazite dating in the western Himalaya, Zanskar, India. Geology, 23, 11351138.

Parrish, R.R., 1990. U-Pb dating of monazite and its application to geological problems. Canadian Journal of Earth Sciences, 27, 1431-1450.

Pyle, J. M. \& Spear, F. S., 1999. Yttrium zoning in garnet: coupling of major and accessory phases during metamorphic reactions. Geological Materials Research, 1, 1-49.

Pyle, J. M. \& Spear, F. S., 2003. Four generations of accessoryphase growth in low-pressure migmatites from SW New Hampshire. American Mineralogist, 88, 338-351.

Pyle, J. M., Spear, F. S., Rudnick, R. L. \& McDonough, W. F., 2001. Monazite-xenotime-garnet equilibrium in metapelites and a new monazite-garnet thermometer. Journal of Petrology, 42, 2083-2107.

Pyle, J. M., Spear, F. S., Cheney, J. T. \& Layne, G., 2005. Monazite ages in the Chesham Pond Nappe, SW New Hampshire, U.S.A.: implications for assembly of central New England thrust sheets. American Mineralogist, 90, 592-606.

Schärer, U., 1984. The effect of initial ${ }^{230}$ Th disequilibrium on young U-Pb ages; the Makalu case, Himalaya. Earth and Planetary Science Letters, 67, 191-204.

Simpson, R. L., Parrish, R. R., Searle, M. P. \& Waters, D. J., 2000. Two episodes of monazite crystallization during metamorphism and crustal melting in the Everest region of the Nepalese Himalaya. Geology, 28, 403-406.

Spear, F. S. \& Pyle, J. M., 2002. Apatite, monazite and xenotime in metamorphic rocks. Reviews in Mineralogy, 48, 293-335.

Spear, F. S., Kohn, M. J. \& Cheney, J. T., 1999. P-T paths from anatectic pelites. Contributions to Mineralogy and Petrology, 134, 17-32.

Stacey, J. S. \& Kramers, J. D., 1975. Approximation of terrestrial lead isotope evolution by a two-stage model. Earth and Planetary Science Letters, 26, 207-221.

Viskupic, K. \& Hodges, K. V., 2001. Monazite-xenotime thermochronometry; methodology and an example from the Nepalese Himalaya. Contributions to Mineralogy and Petrology, 141, 233-247.

Watt, G. R. \& Harley, S. L., 1993. Accessory phase controls on the geochemistry of crustal melts and restites produced during water-undersaturated partial melting. Contributions to Mineralogy and Petrology, 114, 550-566.

Wing, B. N., Ferry, J. M. \& Harrison, T. M., 2003. Prograde destruction and formation of monazite and allanite during contact and regional metamorphism of pelites: petrology and geochronology. Contributions to Mineralogy and Petrology, 145, 228-250.

Wolf, M. B. \& London, D., 1994. Apatite dissolution into peraluminous haplogranitic melts; an experimental study of solubilities and mechanisms. Geochimica et Cosmochimica Acta, $\mathbf{5 8}, 4127-4145$.

Received 26 October 2004; revision accepted 22 April 2005. 